\title{
Corn Stunt Disease: An Ideal Insect-Microbial-Plant Pathosystem for Comprehensive Studies of Vector-Borne Plant Diseases of Corn
}

\author{
Tara-kay L. Jones ${ }^{1,2}$ and Raul F. Medina ${ }^{1, *}$ \\ 1 Department of Entomology, Texas A\&M University, TAMU 2475, College Station, TX 77843-2475, USA; \\ jonestarakay1@tamu.edu \\ 2 Texas A\&M AgriLife Research-Weslaco, 2415 E. Business 83, Weslaco, TX 78596-8344, USA \\ * Correspondence: rfmedina@tamu.edu; Tel.: +1-979-845-4775
}

Received: 14 May 2020; Accepted: 12 June 2020; Published: 14 June 2020

\begin{abstract}
Over 700 plant diseases identified as vector-borne negatively impact plant health and food security globally. The pest control of vector-borne diseases in agricultural settings is in urgent need of more effective tools. Ongoing research in genetics, molecular biology, physiology, and vector behavior has begun to unravel new insights into the transmission of phytopathogens by their insect vectors. However, the intricate mechanisms involved in phytopathogen transmission for certain pathosystems warrant further investigation. In this review, we propose the corn stunt pathosystem (Zea mays-Spiroplasma kunkelii-Dalbulus maidis) as an ideal model for dissecting the molecular determinants and mechanisms underpinning the persistent transmission of a mollicute by its specialist insect vector to an economically important monocotyledonous crop. Corn stunt is the most important disease of corn in the Americas and the Caribbean, where it causes the severe stunting of corn plants and can result in up to $100 \%$ yield loss. A comprehensive study of the corn stunt disease system will pave the way for the discovery of novel molecular targets for genetic pest control targeting either the insect vector or the phytopathogen.
\end{abstract}

Keywords: vector-borne; phytopathogens; insect vectors; corn stunt

\section{Introduction}

More than 700 distinct plant diseases identified as vector-borne pose a significant threat to plant health and food security within agricultural systems all over the world [1-4]. The study of interactions between insect vectors, phytopathogens, and their shared plant hosts is fundamental for the elucidation of clues necessary for developing novel and sustainable control strategies to mitigate losses caused by vector-borne plant diseases. When it comes to understanding the molecular mechanisms involved in insect-pathogen and vector-pathogen interactions, the majority of what we know comes from the studies of Drosophila [5,6] and Aedes or Anopheles mosquitoes [7-9]. While studies using model organisms such as mosquitoes have been important for improving our understanding of pathogen infection mechanisms, this model pathosystem only provides information about the transmission of human and animal diseases. Thus, there is a need to increase our knowledge of the mechanisms used by vectors of plant diseases. In recent years, a surge of studies focusing on hemipteran insect vectors has emerged [10]. However, most of the plant pathogens being studied are plant viruses transmitted in a non-persistent or semi-persistent manner (e.g., Alfamovirus, Fabavirus, Cucumovirus, Potyvirus, Closterovirus, Sequivirus, and Crinivirus) [11-16]. There are also comparatively fewer studies on vector transmitting bacteria, particularly of class Mollicutes than on vector-transmitted viruses. Insect vectors of non-persistently and semi-persistently transmitted viruses only remain viruliferous 
for a short period (seconds to minutes or hours to days but not beyond the molting process of their vectors) [17], and thus a single individual has low chances of transmitting a pathogen to several plants within a field. Devising novel strategies for controlling rapidly spreading diseases in plants will require an increase in the type of phytopathogens and vectors studied. For example, phytopathogens that are persistently transmitted by insects remain within their vectors for prolonged periods (several weeks to months), making them of great significance in the long-term dissemination and widespread movement of vector-borne diseases that are typically harder to control using traditional strategies. Moreover, the majority of studies detailing persistent transmission have focused on phytopathogens that infect dicotyledonous plants such as tomatoes, beans, and peppers [18]. In this review, we call for additional and more extensive studies to fill the knowledge gap that exists in our understanding of the spread of vector-borne phytopathogens that are persistently transmitted to monocotyledonous plants. We propose the use of corn stunt disease, which is caused by Spiroplasma kunkelii and that is persistently transmitted by Dalbulus maidis to Zea mays, as an ideal model system for dissecting the molecular determinants and mechanisms underpinning the insect vector-mollicute interaction of an economically important monocotyledonous crop.

Corn stunt disease has been the most important limiting factor of corn production in the Caribbean and the Americas, including the United States, Mexico, and Central and South America during the 19th and 20th centuries [19-23]. Recently, corn stunt disease has resurfaced, as symptoms were observed in native corn varieties grown in southeast Puebla, Mexico [24]. Corn stunt disease results in severely stunted plants that often produce multiple small ears with loose and/or missing kernels. This disease is caused by Spiroplasma kunkelii, commonly known as the corn stunt spiroplasma (CSS). This bacterial pathogen is transmitted singly or in combination with Maize bushy stunt phytoplasma (MBSP) and/or Maize rayado fino virus (MRFV) to healthy corn plants by the corn leafhopper, Dalbulus maidis, in a persistent-propagative manner. Dalbulus maidis is considered a serious pest of corn in Mexico, the Caribbean basin, and Central and South America, especially because of its competence in phytopathogen transmission and associated yield loss [25-27]. For example, Brazil's corn production during the 2017-2018 period was impacted by a severe D. maidis infestation [28]. Efforts to control D. maidis in Brazil led to economic constraints to local corn producers due to an $85 \%$ increase in pesticide usage compared to the previous seasons. There is no current control strategy established for managing corn stunt disease by directly targeting this phytopathogen. The use of insect-resistant corn germplasm has thus far been unsatisfactory [29]. Control methods, therefore, rely on attempts to either suppress or completely eradicate the insect vector, thus resulting in indirect pathogen control [27]. Indirect corn stunt disease control has been achieved through the application of insecticides, but it is debatable as to whether it produces a significant net return [30]. In addition, the application of insecticides has been recorded as having a potential negative impact on parasitoids and predators of D. maidis [30].

In nature, spiroplasmas exist as both pathogenic (e.g., S. kunkelii causing corn stunt disease in corn, S. citri causing citrus stubborn disease in several plant families, and S. phoeniceum causing the periwinkle yellows disease in periwinkle plants (Table 1)) and non-pathogenic microbes (e.g., Spiroplasma spp. strains in Drosophila co-exist as symbionts) [31]. Pathogenic spiroplasmas have evolved a diverse host range that extends from plants, insects, and crustaceans to most recently affecting humans directly (e.g., a human-infecting spiroplasma was newly identified as a strain of the horse fly symbiont, Spiroplasma turonicum [32]). Arthropod vectors play an important role in the spread of plant pathogenic spiroplasmas, and thus it is important to understand how they interact with their vectors and cause disease epidemics in agricultural settings. In total, mollicutes (i.e., spiroplasmas and phytoplasmas) are responsible for causing plant diseases in over 300 crops [33]. Hence, it is of significance to understand the specific associations and mechanisms that regulate the spread of these phytopathogens in agricultural crops.

Many insect vector-phytopathogen-plant interaction studies focus on the vectoring capacity of insect species that threaten (through a combination of herbivory and pathogen transmission) a wide host plant range, as this is necessary to justify a significant economic threat. Therefore, generalist phytophagous insects, which can pose a serious threat to several different plant species from distinct 
families, are often the preferred choice of study. On the other hand, specialist phytophagous insects that demonstrate feeding behaviors highly specialized on a single host plant species or just a few related ones are lagging [34]. It is also important to recognize that insect vectors, phytopathogens, and host plants form successful interactions through specialization [35]. For example, insect-host plant specificity generally offers increasing developmental benefits in terms of biochemical compatibilities, thus boosting the survivability of the insect species to tolerate plant defenses, manipulate host plants to their benefit, and evolve ways to reduce predation and parasitism [36-39]. Understanding specialized interactions between insect vectors and phytopathogens with their shared host plants can help us piece together the mechanisms and strategies that are used to facilitate herbivory and vector-borne disease epidemiology. Thus, the corn stunt pathosystem could be exploited as a model system that demonstrates successful interactions through specialization (i.e., D. maidis has coevolved and developed as a specialist of corn as an efficient vector of S. kunkelii) [40-44], which makes it ideal for understanding the intricate interactions of phytopathogens persistently transmitted by insect vectors.

Over the last two decades, research on genetics, molecular biology, physiology, and behavioral studies has brought new insights into the mechanisms involved in the insect transmission of phytopathogens. Discoveries from these disciplines have been revolutionized by the development of genetic technologies, including RNA interference (RNAi) and Clustered Regularly Interspaced Short Palindromic Repeats (CRISPR) [45-47]. These new genetic tools offer a promising future for agriculture through genetic pest control, including the design and implementation of novel strategies for managing vector-borne plant diseases. Genetic pest control employs molecular tools to manipulate pest genes, with the primary aim of reducing their population densities [48]. These genetic tools can be further exploited to abolish pathogen transmission without reducing or eliminating an insect vector from a given geographical area. A number of insect pests of crops, as well as human disease vectors, are currently undergoing laboratory assessments and open-release trials $[49,50]$. For example, the population suppression or replacement of laboratory Aedes and Anopheles mosquitoes that are vectors of arboviruses and malaria, respectively, has been achieved using genetic pest control strategies that utilize a gene drive mechanism (reviewed in Macias et al. [51]). Similarly, these may be applied to protecting agricultural systems by specifically targeting and disrupting pathogen transmission by rendering vectors refractory to infection or just abolishing pathogen acquisition and/or transmission [51-56]. To find successful candidates for genetic pest control, much of the recent studies have focused on first achieving a more comprehensive understanding of the complex series of events leading to successful insect vector-phytopathogen-plant interactions [10]. In our proposed model, the corn stunt pathosystem is expected to contribute to the discovery of key candidate genes that could be useful targets for genetic pest control of an insect vector and plant-infecting spiroplasma threatening corn, a staple crop of worldwide importance.

Table 1. List of plant diseases caused by Spiroplasma pathogens, their leafhopper vectors and host plant families.

\begin{tabular}{|c|c|c|c|c|}
\hline Plant Disease & $\begin{array}{c}\text { Spiroplasma } \\
\text { Pathogens }\end{array}$ & Leafhopper Vectors & Host Plant Families & References \\
\hline $\begin{array}{c}\text { Citrus stubborn } \\
\text { disease }\end{array}$ & Spiroplasma citri & $\begin{array}{l}\text { Circulifer haematoceps, Scaphytopius } \\
\text { nitridus Circulifer tenellus, } \\
\text { E Circulifer opacipennis, } \\
\text { E Macrosteles fascifrons Fieber, } \\
\text { Ricaria japonica }\end{array}$ & $\begin{array}{l}\text { Alliaceae, Apiacceae, } \\
\text { Apocynaceae, } \\
\text { Amaryllidaceae, } \\
\text { Asteraceae, Brassicaceae, } \\
\text { Brassicaceae, Crassulaceae, } \\
\text { Cucurbitaceae, } \\
\text { Plantaginaceae, Rosaceae, } \\
\text { Rutaceae, } \\
\text { Scrophulariaceae, } \\
\text { Violaceae }\end{array}$ & {$[57-66]$} \\
\hline
\end{tabular}


Table 1. Cont

\begin{tabular}{|c|c|c|c|c|}
\hline Plant Disease & $\begin{array}{c}\text { Spiroplasma } \\
\text { Pathogens }\end{array}$ & Leafhopper Vectors & Host Plant Families & References \\
\hline $\begin{array}{l}\text { Corn stunt } \\
\text { disease }\end{array}$ & $\begin{array}{l}\text { Spiroplasma } \\
\text { kunkelii }\end{array}$ & $\begin{array}{l}\text { Dalbulus maidis, Dalbulus elimatus, } \\
\text { Dalbulus guevari, } \\
\text { E Dalbulus gelbus } \\
\text { E Dalbulus quinquenotatus } \\
\text { E Dalbulus tripsacoides } \\
\text { E Dalbulus longulus } \\
\text { E Exitianus exitiosus, } \\
\text { E Euscelidius variegatus } \\
\text { E Graminella nigrifrons, } \\
\text { E Stirellus bicolor, }\end{array}$ & Poaceae & {$[21,25,67-69]$} \\
\hline $\begin{array}{c}\text { Periwinkle } \\
\text { yellows disease }\end{array}$ & $\begin{array}{c}\text { Spiroplasma } \\
\text { phoeniceum, } \\
\text { Spiroplasma citri }\end{array}$ & $\begin{array}{l}\text { E Macrosteles fascifrons, } \\
\text { E Cicadulina bipunctella } \\
\text { P Phlogotettix Cyclops } \\
{ }^{P} \text { Balclutha sp. }\end{array}$ & Apocynaceae & {$[56,59,70,71]$} \\
\hline
\end{tabular}

${ }^{\mathrm{E}}$ Experimental insect vectors, ${ }^{\mathrm{P}}$ potential insect vectors (insects tested positive for Spiroplasma in the field but with insufficient evidence of transmission).

\section{Components of Corn Stunt Disease}

\subsection{Dalbulus Maidis}

The corn leafhopper, Dalbulus maidis (DeLong and Wolcott) (Hemiptera: Cicadellidae), is a phloem-feeding specialist of the genus Zea, which evolved in an increasingly close association with modern-day maize cultivars [40,72,73]. Dalbulus maidis undergo a hemimetabolous lifecycle (Figure 1) and only reproduces on species of Zea. Although D. maidis only reproduce on species of $\mathrm{Zea}$, it is known to feed on several other monocotyledonous plant species such as gamagrass and Johnson grass in the absence of corn and teosintes [74]. There is evidence of D. maidis surviving for several months in the absence of host plants in non-irrigated maize-free fields [75]. Its distribution range extends throughout most of the American continent and the Caribbean islands, with Mexico being reported as the center of origin [76]. Under optimal environmental conditions, D. maidis can colonize corn fields quickly and cause severe yield losses, thus resulting in drastic economic losses [77]. For example, during the period 1979-1980 D. maidis occurred in south Florida, United States, and caused a $98.5 \%$ decline in the state's expected corn yield due to direct feeding as well as through disease spread [26,78], which translated into $\$ 60$ million lost in corn production $[20,79]$.

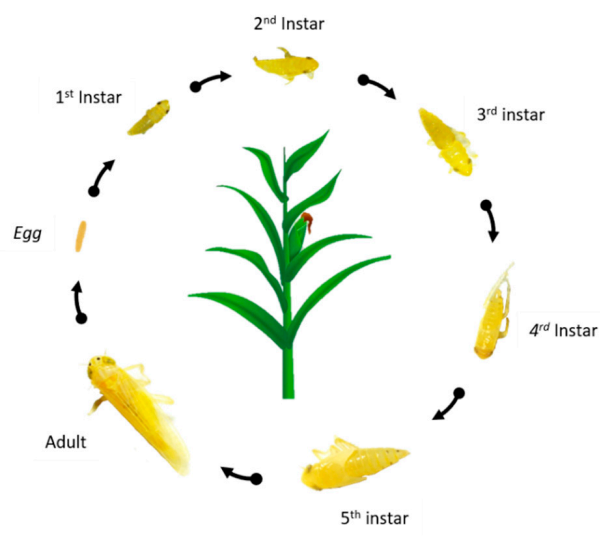

Figure 1. The complete lifecycle of Dalbulus maidis. D. maidis begins as an egg and then undergoes five nymphal instars before reaching adulthood. It takes around 4 to 6 days from oviposition to the emergence of the first nymphal instar. The optimal developmental range for each nymphal stage averages from 3 to 4 days. Adult longevity varies among males and females from an average of 78 and 30 days, respectively. Mature females oviposit an average of 15 eggs per day for most of their adult life [78]. Photo credit: Tara-Kay L. Jones. 


\subsection{Spiroplasma kunkelii}

Spiroplasma kunkelii is a characteristically helical motile bacterium from the class Mollicutes. These cell wall-less bacteria have an internal cytoskeleton, which is composed of fibrils located under the cell membrane [63]. Dalbulus maidis, D. elimatus, and D. guevari are natural vectors of S. kunkelii but there are other leafhopper species (D. gelbus, D. quinquenotatus, D. tripsacoides, D. longulus, Exitianus exitiosus, Graminella nigrifrons, Stirellus bicolor, and Euscelidius variegatus) that have been experimentally proven to transmit the pathogen to healthy corn plants under laboratory conditions [21,25]. The Spiroplasma kunkelii (CR2-3X strain) genome has been fully sequenced and consists of a 1,463,926-bp circular chromosome and four plasmids $[68,80,81]$. Within the S. kunkelii chromosome, there are 1646 protein-coding regions, multiple insertions of Spiroplasma virus sequences, a set of rRNA genes, and 33 tRNA genes [68]. The availability of $S$. kunkelii genomic information facilitates studies of pathogenicity and evolutionary adaptations with plants and insect vectors, respectively, which makes it a suitable candidate for studying its interaction within these disparate hosts where it replicates but causes very distinct outcomes. In addition, the availability of S. kunkelii genomic data is also useful for conducting studies aimed at better understanding the mollicute components that regulate transmission by its insect vectors. Phylogenetically, S. kunkelii clusters with other bacteria in the class Mollicutes and it is most closely related to the plant pathogens S. citri and S. phoeniceum, which affects citrus and periwinkle, respectively [82-84]. Additionally, S. kunkelii is also in the same genetic cluster as the honeybee pathogen, S. melliferum, and thus it could potentially provide insights on the pathogenicity of these distinct organisms [82,83]. While an increasing amount of literature is being published on S. citri due to the economic and agricultural importance of citrus crops, it is important to note that $S$. citri has been reported to have a pathogenic effect on its insect vector as opposed to $S$. kunkelii which seemingly forms an either positive or neutral association with D. maidis, as it has not been found to have a detrimental effect on the insect's longevity or fecundity $[85,86]$. Therefore, more comprehensive studies on the interactions of S. kunkelii and D. maidis are likely to increase our understanding of the molecular bases and biological consequences resulting in the efficient transmission of this mollicute by its main leafhopper vector to maize.

\subsection{Zea mays}

Zea mays, commonly known as corn or maize, is a member of the grass family Poaceae. Corn is a diploid, large grain cereal that originated in Mexico and disseminated further north and south of its center of origin. Corn is one of the most important cereal crops worldwide, ranking third in production following wheat and rice. Furthermore, it has a diverse distribution range, with its capacity to grow on all continents except Antarctica [87]. Corn plays a significant role in human nutrition (it contains $60-68 \%$ starch, $7-15 \%$ protein, and is rich in amino acids and minerals such as phosphorus and potassium), it is extensively used for animal feed and is also utilized for biofuel production as well as in other numerous industrial products [88]. Corn has been established as a genetic model monocotyledonous plant for over a century [89], which makes it an ideal choice for studying molecular interactions amongst insect vectors and their associated phytopathogens in a monocotyledonous crop. There are seven known vector-borne diseases of corn, five of which are viral (i.e., Maize dwarf mosaic potyvirus (A and B), Maize stripe tenuivirus, Maize rayado fino marafivirus, and Maize mosaic nucleorhabdovirus) while the other two are bacterial (i.e., corn stunt spiroplasma and maize bushy stunt phytoplasma). Interestingly, three of the seven vector-borne diseases affecting corn's production are caused by phytopathogens transmitted by D. maidis in a persistent-propagative manner. Corn pathogens transmitted by D. maidis have been reported in all corn-growing regions where the insect is present and have caused damage, ranging from $40 \%-100 \%$ yield loss. Limited scientific information is available regarding the targets and mechanisms of resistance in corn against Spiroplasma infections [67]. For this reason, it is important to understand the components of the corn stunt disease. Studies focusing on the mechanisms of corn pathogen transmission could provide us with major clues on the interactions within this insect vector-phytopathogen-plant triad that might aid in disrupting 
transmission and offering sustainable control strategies against plant diseases in this and/or other monocotyledonous plants.

\section{Insect Vector Interactions with Host Plant and Pathogen}

\subsection{Dalbulus maidis-Spiroplasma kunkelii}

The transmission route of $S$. kunkelii in its D. maidis vector has been documented by several researchers $[33,90,91]$. Spiroplasma kunkelii is acquired by D. maidis as early as several minutes of the insect feeding from the sieve tube of the phloem of infected corn plants. The pathogen is then en-route to the gut, where it is mixed with the gut fluids and then crosses the midgut barriers to enter the hemocoel where it primarily replicates in the hemolymph and follows a complete systematic circulation [33]. The pathogen has a latent period that ranges from 18 to 22 days (depending upon the isolate and titer of the pathogen, as well as depending upon the biotype and age of the insect vector) before it can enter the salivary glands to finally be transmitted to healthy plants. Within the insect vector, S. kunkelii localizes in tissues and organs such as the ovaries, fat body, cytoplasmic vesicles, and salivary glands, and it is also detected in the gut lumen, where it is retained within a bacterialiferous vector for up to 45 days $[33,90]$.

The leafhopper vector transmission of Spiroplasma is mediated by hemolymph proteins, functional peptides, pathogen proteins, and enzymes. To date, there has not been any extensive study of functional vector derived proteins and pathogen proteins involved in the D.maidis transmission of S. kunkelii. In a related Spiroplasma species, S. citri, a correlation exists between the leafhopper transmission efficiency and S. citri's ability to bind a phosphoglycerate kinase (PGK) to the leafhopper vector's actin [92]. This binding of $S$. citri PGK to its leafhopper vector's actin protein resulted in the cellular internalization of the phytopathogen [92]. Leafhopper membrane proteins have been hypothesized to play important roles in the spiroplasma barrier crossing and transmission through the process of receptor-mediated endocytosis [33,92-94]. Some potential transmission proteins already identified are solute-binding proteins (e.g., Sc76 and P32 protein identified in S. citri); adhesion-associated proteins (e.g., ScARPs); and spiralin, which has been shown to bind with leafhopper's glycoproteins [92,95]. The genome sequence of S.kunkelii revealed the presence of putative virulence genes encoding P123, P58, P54, and P18 which are also present in the transmissible S. citri genome and represent a deletion in the non-transmissible $S$. citri lines [80]. Functional molecular analyses conducted by Breton et al. [96] identified the role of pScil-6 plasmid in conferring the transmissibility of S. citri. In this study, Breton et al. [96] further elucidated that the protein $\mathrm{pE}$ (a derivative $S$. citri plasmid) was a replicon protein necessary for the replication of pScil-6. A soj-encoded polypeptide was also found to be likely involved in plasmid partitioning, and together these proteins enable the transmissibility of Spiroplasma [96]. While these proteins have been identified in a closely related spiroplasma-insect vector pathosystem, further analysis is necessary to uncover more candidates and further elucidate their functional role in the transmission cycle of $S$. kunkelii by D. maidis.

Comparatively, non-pathogenic Spiroplasmas, such as those detected in Drosophila species, exhibit strategies to evade host immune defenses and result in commensalism interactions that accommodate their survival and transmission at no fitness cost to the host $[97,98]$. In contrast, other non-pathogenic spiroplasmas have a more mutualistic interaction with their insect hosts, such in Acyrthosiphon pisum, where fitness costs associated with hosting spiroplasmas are compensated by increased defenses against threats such as parasitism [99]. Additionally, in D. melanogaster, the presence of non-pathogenic Spiroplasmas may co-occur with Wolbachia symbionts, which have been found to reduce the pathogenicity of infectious Photorhabdus luminescens bacteria as well as triggering immune-signaling responses [97]. Non-pathogenic Spiroplasmas are generally restricted to the gut of their insect hosts compared to pathogenic Spiroplasmas, which can invade the hemolymph and other host tissues [90]. Another differentiating trait related to the pathogenicity of Spiroplasmas are sex-ratio disorders, which have been observed in pathogenic strains [100]. For example, S. poulsonii in tropical 
Drosophila species, during transovarial transmission, kill male progeny of infected females [101]. In some beetle species, Spiroplasma male-killing has been documented [102,103]. There is no published evidence of male-killing in insect vectors of plant diseases. The exploration of D. maidis-S. kunkelii interactions could reveal vector fitness costs and open a path for us to hijack these mechanisms as part of genetic vector control strategies.

\subsection{Dalbulus maidis-Zea mays}

The corn leafhopper interaction with corn is thought to be mediated by evolutionary mechanisms triggered throughout corn's domestication from its teosinte relative, the annual teosinte Zea mays subsp. parviglumis Iltis and Doebley, over 9000 years ago in central Mexico [42,104]. To date, little is known about the genetic mechanisms mediating $D$. maidis successful adaptation to corn, except that there are D. maidis populations that are genetically distinct from each other across the transition from wild to domesticated corn and well adapted to either one of these different host plants [42]. Several studies that previously assessed the $D$. maidis and corn interaction have specifically looked at the insect vector performance (e.g., survivorship, and reproduction) $[26,40,73,105,106]$. For example, Moya-Raygoza and Garcia-Medina [106] showed that the reproductive capacity of D. maidis plays a crucial role in its colonization success. The higher reproductive capacity of $D$. maidis has been proven to be a positively correlated factor of higher population density in regions of Argentina and Mexico [106]. On the other hand, the plant chemistry of corn (particularly the expression of jasmonic acid (JA) and salicylic acid (SA)) could explain at least in part the defense mechanisms that might play a role in the adaptation and performance of $D$. maidis on corn compared to teosintes $[107,108]$. For example, D. maidis herbivory has been shown to cause a higher expression of SA on corn, while this same challenge induced a higher expression of JA in teosintes, suggesting that this defense response has changed throughout corn breeding and domestication [109]. These findings provide a reasonable clue to potential evolutionary patterns in D. maidis adaptation that might dictate the differences observed of higher abundance of this insect vector in corn than in its teosinte progenitor [110]. Although not yet tested, there might also be other genetic components contributing to the successful performance of $D$. maidis on corn compared to teosintes. Therefore, we also proposed more comprehensive molecular and genetic studies to further elucidate the interaction between $D$. maidis and corn that ultimately benefits pathogen acquisition and transmission from its confinement within the plant host vasculature.

\section{Plant-Pathogen Interaction}

\subsection{Zea mays-Spiroplasma kunkelii}

Spiroplasma kunkelii colonizes and moves through the flowing photosynthate (sugars and other energy-rich compounds) within the phloem of corn plants and localizes in the actively growing regions such as the younger leaves, roots, flowers, and fruits [19]. The symptoms of corn stunt disease vary according to the titer of $S$. kunkelii in infected corn plants and the susceptibility of the host plant [111]. Typically, diseased corn plants are identified by chlorotic stripes, which extend from the base of the leaf laminas towards the apex or leaf margins, red to purple streaks, as well as stunted growth as a result of the shortening of internodes [111,112]. Similar corn stunting symptoms are caused by Maize bushy stunt phytoplasma (MBSP), where corn plants are observed with small reddish leaves and/or leaves with red midribs or leaves with yellow or chlorotic stripes. However, disease diagnosis can be achieved by the detection of S. kunkelii and/or MBSP from cornfield samples using laboratory techniques such as enzyme-linked immunosorbent assay (ELISA) [113] and polymerase chain reaction (PCR) $[114,115]$. The symptom expression of corn stunt disease ranges from 15 to 40 days of initial transmission of S. kunkelii by D. maidis $[20,111]$. In severe corn stunt disease, there are generally reduced to no corn kernels produced. 


\subsection{Plant Immunity}

Plant defense mechanisms are triggered by the presence of infectious agents and/or stimulated by the infestation of an herbivore [116-119]. Upon contact with plant tissues, pathogens and herbivores release molecules which are known as elicitors [120-125]. Elicitors are categorized as either general or specific. General elicitors are associated with chemicals, herbivores, pathogens, and non-pathogenic/or beneficial microbes. General elicitors of insects are molecules designated as DAMPs (Damage-associated Molecular Patterns), whereas those of pathogens are PAMPs (Pathogen-Associated Molecular Patterns) [126,127]. DAMPs and PAMPs are not specific to host plant cultivar and trigger general resistance. The recognition of DAMPs and PAMPs mediated by plasma membrane-localized pattern-recognition receptors (PRRs) triggers a cascade of reactions within the host plant that leads to a primary innate immunity (basal resistance) called PAMP-triggered immunity (PTI) [128]. Specific elicitors are unique molecules, referred to as avirulence (Avr) proteins and are formed by specialized pathogen races or strains that induce resistance responses that are related to specific host plant cultivars that carry a complementary disease resistance gene ( $R$ gene) $[129,130]$. The recognition of Avr proteins and the expression of the complimentary $R$ gene by host plants leads to a secondary innate immunity called effector-triggered immunity (ETI) [131]. The activation of both PTI and ETI reduces infection within a host plant [132-134]. Because corn is an established model crop, there are already identified cellular DAMPs and PAMPs response paths (for example, the early production of reactive oxygen species (ROS) $[135,136]$, the activation of mitogen-activated protein kinases (MAPK) [137-139], and Ca2+ signaling [140]), as well as pathogen recognition receptors (PRRs) (for example, receptor-like kinases (RLK) and receptor-like protein (RLP)) that are activated and are known to have roles in pathogen immunity and herbivory through elicitor-binding [141-144]. Though a detailed framework on corn defense strategies is already known, further studies are needed to provide information on how pathogens such as $S$. kunkelii and insect herbivores such as D. maidis evade and manipulate the complete expression of corn resistance. For example, a study of plant-pathogen molecular interaction by Oliveira-Garcia and Deising [145] shows that a down-regulation of key effector components (i.e., $\beta-1,6$-glucan synthesis genes KRE5 and KRE6) in the biotrophic hyphae of Colletotrichum graminicola manipulate the expression of PTI in corn and facilitate the compatibility necessary for infection to occur. Similarly, Levy et al. [146] studied the molecular interaction between Candidatus Liberibacter solanacearum and tomato plants. In the said study, Levy et al. [146] identified an important protein effector (Lso-HPE1) which plays a role in the suppression of plant immune response. The identification of key effector proteins that suppress plant defense response and thus promote disease susceptibility in plant can be used as targets in developing genetic control strategies against plant disease agents. Similar studies as Oliveira-Garcia and Deising [145] and Levy et al. [146] can be conducted using the corn stunt pathosystem to unravel important details involved in the defense and resistance of bacterial diseases that are plaguing monocotyledonous crops.

\section{Conclusions and Future Perspectives}

The corn stunt pathosystem (Zea mays-Spiroplasma kunkelii-Dalbulus maidis) is identified as a suitable model system for increasing our understanding of vector-borne plant diseases that pose a threat to global food security. Although significant research efforts are aimed at increasing our understanding of vector-borne diseases, there is still limited scientific knowledge of the molecular mechanisms mediating specific vector-borne diseases. To fill this gap in knowledge and be able to devise novel control strategies against vector-borne plant diseases, it is essential to accumulate information involving specialist vectors and their role in bacterial pathogen transmission and disease development in monocotyledonous plants. The mechanisms mediating bacterial disease development in monocots and the transmission of pathogens by specialist insect vectors is an understudied area of insect-pathogen-plant interaction $[147,148]$. Therefore, in this review we encourage experimental research aimed at improving our understanding of how specialized biological systems (e.g., specialist vectors transmitting plant bacterial pathogens) interact. The interaction between Dalbulus maidis, 
Spiroplasma kunkelii, and Zea mays meets the criteria of a specialized biological system, as we have discussed throughout this review. Using the corn stunt pathosystem to study the mechanisms of vector-borne disease can contribute to our understanding not only of Spiroplasma-related plant diseases but also of phytoplasma and viral plant diseases, as D. maidis can be described as a super-vector due to its efficiency in transmitting MBSP (a phytoplasma pathogen) and MRFV (a viral pathogen) to corn plants. Scientific insights provided by the study of the corn stunt pathosystem may be applicable to other pathosystems (e.g., Bermudagrass stunt disease and Ratoon stunt disease of sugarcane, which cause major challenges in several other plants [149-151]). Finally, studying the molecular interactions taking place during corn stunt disease infection may provide candidate genes and molecules that can be targeted as part of genetic pest control strategies that can be used for the successful disruption of pathogen transmission by insect vectors to host plants.

Author Contributions: Conceptualization, T.-k.L.J. and R.F.M.; Literature curation/investigation, T.-k.L.J.; Validation, R.F.M.; Writing-Draft preparation, T.-k.L.J.; Writing-Review and editing, R.M. and T.-k.L.J.; Supervision. R.F.M. All authors have read and agreed to the published version of this manuscript.

Funding: This work was supported in part by the National Institute of Food and Agriculture, U.S. Department of Agriculture Hatch Program (TEX09185 to RFM).

Acknowledgments: We would like to thank Ismael E. Badillo for editing the early versions of this manuscript. We also thank Crys Wright for formatting the photos used to create Figure 1 in the manuscript.

Conflicts of Interest: The authors declare no conflict of interest.

\section{References}

1. Hogenhout, S.A.; Ammar el, D.; Whitfield, A.E.; Redinbaugh, M.G. Insect vector interactions with persistently transmitted viruses. Annu. Rev. Phytopathol. 2008, 46, 327-359. [CrossRef]

2. Fletcher, J.; Wayadande, A. Fastidious vascular-colonizing bacteria. The Plant Health Instructor. Am. Phytopathol. Soc. 2002. [CrossRef]

3. Weintraub, P.G.; Beanland, L. Insect vectors of phytoplasmas. Annu. Rev. Entomol. 2006, 51, 91-111. [CrossRef]

4. Hammond, R.W.; Bedendo, I.P. Molecular confirmation of Maize rayado fino virus as the Brazilian corn streak virus. Sci. Agric. 2005, 62, 601-603. [CrossRef]

5. Tzou, P.; De Gregorio, E.; Lemaitre, B. How Drosophila combats microbial infection: A model to study innate immunity and host-pathogen interactions. Curr. Opin. Microbiol. 2002, 5, 102-110. [CrossRef]

6. Dionne, M.S.; Schneider, D.S. Models of infectious diseases in the fruit fly Drosophila melanogaster. Dis. Model. Mech. 2008, 1, 43-49. [CrossRef] [PubMed]

7. Lundstrom, J.O. Mosquito-borne viruses in western Europe: A review. J. Vector Ecol. 1999, 24, 1-39. [PubMed]

8. Ciota, A.T.; Kramer, L.D. Vector-virus interactions and transmission dynamics of West Nile virus. Viruses 2013, 5, 3021-3047. [CrossRef] [PubMed]

9. Hamel, R.; Liégeois, F.; Wichit, S.; Pompon, J.; Diop, F.; Talignani, L.; Thomas, F.; Desprès, P.; Yssel, H.; Missé, D. Zika virus: Epidemiology, clinical features and host-virus interactions. Microb. Infect. 2016, 18, 441-449. [CrossRef] [PubMed]

10. Doumayrou, J.; Sheber, M.; Bonning, C.B.; Miller, A.W. Role of Pea enation mosaic virus coat protein in the host plant and aphid Vector. Viruses 2016, 8, 312. [CrossRef]

11. Whitfield, A.E.; Falk, B.W.; Rotenberg, D. Insect vector-mediated transmission of plant viruses. Virology 2015, 479-480, 278-289. [CrossRef] [PubMed]

12. Wang, R.-L.; Zhu-Salzman, K.; Elzaki, M.E.A.; Huang, Q.-Q.; Chen, S.; Ma, Z.-H.; Liu, S.-W.; Zhang, J.-E. Mikania micrantha wilt virus alters insect vector's host preference to enhance its own spread. Viruses 2019, 11, 336. [CrossRef] [PubMed]

13. Bosquée, E.; Yin, R.L.; Bragard, C.; Yong, L.; Chen, J.L.; Francis, F. Transmission efficiency of Cucumber mosaic virus by Myzus persicae according to virus strain and aphid clone from China. Asian J. Plant Pathol. 2016, 10, 61-66. [CrossRef]

14. Berthelot, E.; Khelifa, M.; Blanc, S.; Drucker, M. Potyvirus: How the Aphid Activates their Transmission? Végéphyl: Alfortville, France, 2018; pp. 38-46. 
15. Stewart, L.R.; Jarugula, S.; Zhao, Y.; Qu, F.; Marty, D. Identification of a Maize chlorotic dwarf virus silencing suppressor protein. Virology 2017, 504, 88-95. [CrossRef] [PubMed]

16. Wintermantel, W.M.; Gilbertson, R.L.; McCreight, J.D.; Natwick, E.T. Host-specific relationship between virus titer and whitefly transmission of Cucurbit yellow stunting disorder virus. Plant Dis. 2016, 100, 92-98. [CrossRef]

17. Ng, J.C.; Falk, B.W. Virus-vector interactions mediating nonpersistent and semipersistent transmission of plant viruses. Annu. Rev. Phytopathol. 2006, 44, 183-212. [CrossRef]

18. Chen, G.; Su, Q.; Shi, X.; Pan, H.; Jiao, X.; Zhang, Y. Persistently transmitted viruses restrict the transmission of other viruses by affecting their vectors. Front. Physiol. 2018, 9, 1261. [CrossRef]

19. Gussie, J.S.; Fletcher, J.; Claypool, P.L. Movement and multiplication of Spiroplasma kunkelii in corn. Phytopathology 1995, 85, 1093-1098. [CrossRef]

20. Bradfute, O.E. Corn stunt spiroplasma and viruses associated with a maize disease epidemic in Southern Florida. Plant Dis. 1981, 65, 837-841. [CrossRef]

21. Tsai, J.; Miller, J. Corn Stunt Spiroplasma; Plant Pathology Circular No. 373; Florida Department of Agriculture and Consumer Services: Tallahassee, FL, USA, 1995.

22. Hruska, A.J.; Gladstone, S.M.; Obando, R. Epidemic roller coaster: Maize stunt disease in Nicaragua. Am. Entomol. 1996, 42, 248-252. [CrossRef]

23. Brewbaker, J.L. Diseases of maize in the wet lowland tropics and the collapse of the Classic Maya civilization. Econ. Bot. 1979, 33, 101-118. [CrossRef]

24. Pérez-López, E.; Olivier, C.Y.; Luna-Rodríguez, M.; Rodríguez, Y.; Iglesias, L.G.; Castro-Luna, A.; Adame-García, J.; Dumonceaux, T.J. Maize bushy stunt phytoplasma affects native corn at high elevations in Southeast Mexico. Eur. J. Plant Pathol. 2016, 963-971. [CrossRef]

25. Nault, L.R. Evolution of an insect pest: Maize and the corn leafhopper, a case study. Maydica 1990, 35, 165-175.

26. Summers, C.G.; Newton, A.S., Jr.; Opgenorth, D.C. Overwintering of Corn Leafhopper, Dalbulus maidis (Homoptera: Cicadellidae), and Spiroplasma kunkelii (Mycoplasmatales: Spiroplasmataceae) in California's San Joaquin Valley. Environ. Entomol. 2004, 33, 1644-1651. [CrossRef]

27. Pérez-López, E.; Wist, T.; Rodríguez, Y.; Luna-Rodríguez, M.; Olivier, C.Y. Maize bushy stunt in native corn: Implications for Mexican "subsistence farmers". Environ. Dev. Sustain. 2018, 20, 1797-1805. [CrossRef]

28. Gottems, L. Sales of Insecticides for Corn Leafhopper Control Jump in Brazil. Agro News, 3 May 2018.

29. Carpane, P.D. Host Resistance and Diversity of Spiroplasma Kunkelii as Components of Corn Stunt Disease. Ph.D. Thesis, Oklahoma State University, Stillwater, OK, USA, December 2007.

30. Hruska, A.J.; Peralta, M.G. Maize response to corn leafhopper (Homoptera: Cicadellidae) infestation and achaparramiento disease. J. Econ. Entomol. 1997, 90, 604-610. [CrossRef]

31. Mateos, M.; Castrezana, S.J.; Nankivell, B.J.; Estes, A.M.; Markow, T.A.; Moran, N.A. Heritable endosymbionts of Drosophila. Genetics 2006, 174, 363-376. [CrossRef]

32. Aquilino, A.; Masiá, M.; López, P.; Galiana, A.J.; Tovar, J.; Andrés, M.; Gutiérrez, F. First human systemic infection caused by Spiroplasma. J. Clin. Microbiol. 2015, 53, 719-721. [CrossRef]

33. Özbek, E.; Miller, S.A.; Meulia, T.; Hogenhout, S.A. Infection and replication sites of Spiroplasma kunkelii (Class: Mollicutes) in midgut and Malpighian tubules of the leafhopper Dalbulus maidis. J. Invertebr. Pathol. 2003, 82, 167-175. [CrossRef]

34. Termonia, A.; Hsiao, T.H.; Pasteels, J.M.; Milinkovitch, M.C. Feeding specialization and host-derived chemical defense in Chrysomeline leaf beetles did not lead to an evolutionary dead end. Proc. Natl. Acad. Sci. USA 2001, 98, 3909. [CrossRef]

35. Giron, D.; Dubreuil, G.; Bennett, A.; Dedeine, F.; Dicke, M.; Dyer, L.A.; Erb, M.; Harris, M.O.; Huguet, E.; Kaloshian, I.; et al. Promises and challenges in insect-plant interactions. Entomol. Exp. Appl. 2018, 166, 319-343. [CrossRef]

36. Krieger, R.I.; Feeny, P.P.; Wilkinson, C.F. Detoxication enzymes in the guts of caterpillars: An evolutionary answer to plant defenses? Science 1971, 172, 579-581. [CrossRef] [PubMed]

37. Ali, J.G.; Agrawal, A.A. Specialist versus generalist insect herbivores and plant defense. Trends Plant Sci. 2012, 17, 293-302. [CrossRef] [PubMed]

38. Zvereva, E.L.; Kozlov, M.V. The costs and effectiveness of chemical defenses in herbivorous insects: A meta-analysis. Ecol. Monogr. 2016, 86, 107-124. [CrossRef] 
39. Engler-Chaouat, H.S.; Gilbert, L.E. De novo synthesis vs. sequestration: Negatively correlated metabolic traits and the evolution of host plant specialization in cyanogenic butterflies. J. Chem. Ecol. 2007, 33, 25-42. [CrossRef]

40. Bellota, E.; Dávila-Flores, A.; Bernal, J.S. A Bird in the Hand Versus Two in the Bush? The Specialist Leafhopper Dalbulus maidis (Hemiptera: Cicadellidae) Does Not Discriminate Against Sub-optimal Host Plants (Zea spp.). Neotrop. Entomol. 2018, 47, 171-180. [CrossRef]

41. Ebbert, M.A.; Nault, L.R. Improved overwintering ability in Dalbulus maidis (Homoptera: Cicadellidae) vectors infected with Spiroplasma kunkelii (Mycoplasmatales: Spiroplasmataceae). Environ. Entomol. 1994, 23, 634-644. [CrossRef]

42. Medina, R.F.; Reyna, S.M.; Bernal, J.S. Population genetic structure of a specialist leafhopper on Zea: Likely anthropogenic and ecological determinants of gene flow. Entomol. Exp. Appl. 2012, 142, 223-235. [CrossRef]

43. Moya-Raygoza, G.; Nault, L.R. Transmission biology of Maize bushy stunt phytoplasma by the corn leafhopper (Homoptera: Cicadellidae). Ann. Entomol. Soc. Am. 1998, 91, 668-676. [CrossRef]

44. Nault, L.R.; Delong, D.M. Evidence for co-evolution of leafhoppers in the genus Dalbulus (Cicadellidae: Homoptera) with maize and its ancestors. Ann. Entomol. Soc. Am. 1980, 73, 349-353. [CrossRef]

45. Puschnik, A.S.; Majzoub, K.; Ooi, Y.S.; Carette, J.E. A CRISPR toolbox to study virus-host interactions. Nat. Rev. Microbiol. 2017, 15, 351-364. [CrossRef] [PubMed]

46. Kanakala, S.; Ghanim, M. RNA interference in insect vectors for plant viruses. Viruses 2016, 8, 329. [CrossRef] [PubMed]

47. Badillo-Vargas, I.E.; Rotenberg, D.; Schneweis, B.A.; Whitfield, A.E. RNA interference tools for the western flower thrips, Frankliniella occidentalis. J. Insect Physiol. 2015, 76, 36-46. [CrossRef] [PubMed]

48. Alphey, N.; Bonsall, M.B. Genetics-based methods for agricultural insect pest management. Agric. For. Entomol. 2018, 20, 131-140. [CrossRef] [PubMed]

49. Harvey-Samuel, T.; Morrison, N.I.; Walker, A.S.; Marubbi, T.; Yao, J.; Collins, H.L.; Gorman, K.; Davies, T.G.E.; Alphey, N.; Warner, S. Pest control and resistance management through release of insects carrying a male-selecting transgene. BMC Biol. 2015, 13, 49. [CrossRef]

50. Papathanos, P.A.; Bourtzis, K.; Tripet, F.; Bossin, H.; Virginio, J.F.; Capurro, M.L.; Pedrosa, M.C.; Guindo, A.; Sylla, L.; Coulibaly, M.B.; et al. A perspective on the need and current status of efficient sex separation methods for mosquito genetic control. Parasites Vectors 2018, 11, 654. [CrossRef]

51. Macias, V.; Ohm, J.; Rasgon, J. Gene drive for mosquito control: Where did it come from and where are we headed? Int. J. Environ. Res. Public Health 2017, 14, 1006. [CrossRef]

52. De Lara Capurro, M.; Coleman, J.; Beerntsen, B.T.; Myles, K.M.; Olson, K.E.; Rocha, E.; Krettli, A.U.; James, A.A. Virus-expressed, recombinant single-chain antibody blocks sporozoite infection of salivary glands in Plasmodium gallinaceum-infected Aedes aegypti. Am. J. Trop. Med. Hyg. 2000, 62, 427-433. [CrossRef]

53. Moreira, L.A.; Ito, J.; Ghosh, A.; Devenport, M.; Zieler, H.; Abraham, E.G.; Crisanti, A.; Nolan, T.; Catteruccia, F.; Jacobs-Lorena, M. Bee venom phospholipase inhibits malaria parasite development in transgenic mosquitoes. J. Biol. Chem. 2002, 277, 40839-40843. [CrossRef]

54. Abraham, E.G.; Cha, S.-J.; Jacobs-Lorena, M. Towards the genetic control of insect vectors: An overview. Entomol. Res. 2007, 37, 213-220. [CrossRef]

55. Dyck, V.A.; Hendrichs, J.; Robinson, A.S. Sterile Insect Technique: Principles and Practice in Area-Wide Integrated Pest Management; Springer Science \& Business Media: Dordrecht, The Netherlands, 2006.

56. Cacciola, S.O.; Bertaccini, A.; Pane, A.; Furneri, P.M. Spiroplasma spp.: A plant, arthropod, animal and human pathogen. Citrus Pathol. 2017, 31. [CrossRef]

57. Rossi, V. Scientific Opinion on the pest categorisation of Spiroplasma citri. EFSA J. 2014, 12, 1-29.

58. Gulua, L. Study of Citrus Stubborn Disease Physico Chemical and Biological Symptoms in Georgian Orange Orchards; Bulletin of the Georgia Academy of Science: Atlanta, GA, USA, 2004.

59. Nejat, N.; Vadamalai, G.; Sijam, K.; Dickinson, M. First Report of Spiroplasma citri (-Induced) Associated with Periwinkle Lethal Yellows in Southeast Asia. Plant Dis. 2011, 95, 1312. [CrossRef] [PubMed]

60. Neriya, Y.; Maejima, K.; Nijo, T.; Tomomitsu, T.; Yusa, A.; Himeno, M.; Netsu, O.; Hamamoto, H.; Oshima, K.; Namba, S. Onion yellow phytoplasma P38 protein plays a role in adhesion to the hosts. FEMS Microbiol. Lett. 2014, 361, 115-122. [CrossRef]

61. El-Fatah, W.; Egiza, A.; Youssef, S.; Shalaby, A. Isolation and Identification of Spiroplasma citri Associated with Citrus Stubborn Disease in Egypt. Int. J. Adv. Res. Biol. Sci. 2016, 3, 223-231. 
62. Davis, R.E.; Shao, J.; Zhao, Y.; Gasparich, G.E.; Gaynor, B.J.; Donofrio, N. Complete genome sequence of Spiroplasma citri Strain R8-A2(T), causal agent of stubborn disease in citrus species. Genome Announc. 2017, 5, e00206-17. [CrossRef]

63. Bové, J.M.; Renaudin, J.; Saillard, C.; Foissac, X.; Garnier, M. Spiroplasma citri, a plant pathogenic mollicute: Relationships with its two hosts, the plant and the leafhopper vector. Annu. Rev. Phytopathol. 2003, 41, 483-500. [CrossRef]

64. Dubrana, M.-P.; Béven, L.; Arricau-Bouvery, N.; Duret, S.; Claverol, S.; Renaudin, J.; Saillard, C. Differential expression of Spiroplasma citri surface protein genes in the plant and insect hosts. BMC Microbiol. 2016, 16, 53. [CrossRef]

65. Nielson, M.W.; Morgan, L.A. Developmental biology of the leafhopper, Scaphytopius nitridus (Homoptera: Cicadellidae), with notes on distribution, hosts, and interspecific breeding. Ann. Entomol. Soc. Am. 1982, 75, 350-352. [CrossRef]

66. Allen, R.M. Cultivation in vitro of spiroplasmas from six plant hosts and two leafhopper vectors in Arizona. Plant Dis. 1982, 66, 669. [CrossRef]

67. Carloni, E.; Carpane, P.; Paradell, S.; Laguna, I.; Pecci, M.P. Presence of Dalbulus maidis (Hemiptera: Cicadellidae) and of Spiroplasma kunkelii in the temperate region of Argentina. J. Econ. Entomol. 2013, 106, 1574-1581. [CrossRef] [PubMed]

68. Davis, R.E.; Shao, J.; Dally, E.L.; Zhao, Y.; Gasparich, G.E.; Gaynor, B.J.; Athey, J.C.; Harrison, N.A.; Donofrio, N. Complete genome sequence of Spiroplasma kunkelii Strain CR2-3x, causal agent of corn stunt disease in Zea mays L. Genome Announc. 2015, 3, e01216-15. [CrossRef] [PubMed]

69. Jurga, M.; Zwolińska, A. Phytoplasmas in Poaceae species: A threat to the most important cereal crops in Europe. J. Plant Pathol. 2020, 1-11. [CrossRef]

70. Davis, R.E.; Shao, J.; Zhao, Y.; Wei, W.; Bottner-Parker, K.; Silver, A.; Stump, Z.; Gasparich, G.E.; Donofrio, N. Complete genome sequence of Spiroplasma phoeniceum strain P40T, a plant pathogen isolated from diseased plants of Madagascar periwinkle [Catharanthus roseus (L.) G. Don]. Microbiol. Resour. Announc. 2019, 8, e01612-18. [CrossRef]

71. Chen, W.-Y.; Huang, Y.-C.; Tsai, M.-1.; Lin, C.-P. Detection and identification of a new phytoplasma associated with periwinkle leaf yellowing disease in Taiwan. Australas. Plant Pathol. 2011, 40, 476-483. [CrossRef]

72. Medina, R.F.; Dickey, A.M.; Harrison, K.; Miller, G.L. Host-associated differentiation in a pecan and water hickory Aphidomorpha community. Entomol. Exp. Appl. 2017, 162, 366-378. [CrossRef]

73. Dávila-Flores, A.M.; DeWitt, T.J.; Bernal, J.S. Facilitated by nature and agriculture: Performance of a specialist herbivore improves with host-plant life history evolution, domestication, and breeding. Oecologia 2013, 173, 1425-1437. [CrossRef]

74. Pitre, H.N. Observations on the life cycle of Dalbulus maidis on three plant species. Fla. Entomol. 1970, 33-37. [CrossRef]

75. Moya-Raygoza, G.; Hogenhout, S.A.; Nault, L.R. Habitat of the corn leafhopper (Hemiptera: Cicadellidae) during the dry (winter) season in Mexico. Environ. Entomol. 2014, 36, 1066-1072. [CrossRef]

76. Palomera, V.; Bertin, S.; Rodríguez, A.; Bosco, D.; Virla, E.; Moya-Raygoza, G. Is There any Genetic Variation among Native Mexican and Argentinian Populations of Dalbulus maidis (Hemiptera: Cicadellidae)? Fla. Entomol. 2012, 95, 150-155. [CrossRef]

77. Wilson, M.R. A handbook of leafhopper and planthopper vectors of plant disease. Bull. Insectol. 2007, 60, 175.

78. Tsai, J.H. Corn Leafhopper, Dalbulus maidis (Delong and Wolcott) (Hemiptera: Cicadellidae). In Encyclopedia of Entomology; Capinera, J.L., Ed.; Springer: Dordrecht, The Netherlands, 2008; pp. 1072-1074.

79. Nault, L.R.; Bradfute, O.E. "Corn Stunt: Involvement of a Complex of Leafhopper-Borne Pathogens" Corn Stunt: Involvement of a Complex of Leafhopper-Borne Pathogens; Academic Press: Cambridge, MA, USA, 1979; pp. 561-586.

80. Bai, X.; Hogenhout, S.A. A genome sequence survey of the mollicute corn stunt spiroplasma Spiroplasma kunkelii. FEMS Microbiol. Lett. 2002, 210, 7-17. [CrossRef] [PubMed]

81. Dally, E.L.; Barros, T.S.L.; Zhao, Y.; Lin, S.; Roe, B.A.; Davis, R.E. Physical and genetic map of the Spiroplasma kunkelii CR2-3x chromosome. Can. J. Microbiol. 2006, 52, 857-867. [CrossRef] [PubMed]

82. Lo, W.-S.; Chen, L.-L.; Chung, W.-C.; Gasparich, G.E.; Kuo, C.-H. Comparative genome analysis of Spiroplasma melliferum IPMB4A, a honeybee-associated bacterium. BMC Genom. 2013, 14, 22. [CrossRef] [PubMed] 
83. Ku, C.; Lo, W.-S.; Chen, L.-L.; Kuo, C.-H. Complete genomes of two dipteran-associated spiroplasmas provided insights into the origin, dynamics, and impacts of viral invasion in spiroplasma. Genom. Biol. Evol. 2013, 5, 1151-1164. [CrossRef] [PubMed]

84. Gasparich, G.E.; Whitcomb, R.F.; Dodge, D.; French, F.E.; Glass, J.; Williamson, D.L. The genus Spiroplasma and its non-helical descendants: Phylogenetic classification, correlation with phenotype and roots of the Mycoplasma mycoides clade. Int. J. Syst. Evol. Microbiol. 2004, 54, 893-918. [CrossRef]

85. Ammar, E.-D.; Gasparich, G.E.; Hall, D.G.; Hogenhout, S.A. Spiroplasma-like organisms closely associated with the gut in five leafhopper species (Hemiptera: Cicadellidae). Arch. Microbiol. 2011, 193, 35-44. [CrossRef]

86. Nault, L.R. "Evolutionary Relationships between Maize Leafhoppers and Their Host Plants" The Leafhoppers and Planthoppers; Wiley: New York, NY, USA, 1985; pp. 309-330.

87. Ramirez-Cabral, N.Y.Z.; Kumar, L.; Shabani, F. Global alterations in areas of suitability for maize production from climate change and using a mechanistic species distribution model (CLIMEX). Sci. Rep. 2017, 7, 5910. [CrossRef]

88. Serna-Saldivar, S.O.; Carrillo, E.P. Food uses of whole corn and dry-milled fractions. In Corn; Elsevier: Amsterdam, The Netherlands, 2019; pp. 435-467.

89. Yang, N.; Liu, J.; Gao, Q.; Gui, S.; Chen, L.; Yang, L.; Huang, J.; Deng, T.; Luo, J.; He, L. Genome assembly of a tropical maize inbred line provides insights into structural variation and crop improvement. Nat. Genet. 2019, 51, 1052-1059. [CrossRef]

90. Whitcomb, R.F.; Chen, T.A.; Williamson, D.L.; Liao, C.; Tully, J.G.; Bové, J.M.; Mouches, C.; Rose, D.L.; Coan, M.E.; Clark, T.B. Spiroplasma kunkelii sp. nov.: Characterization of the etiological agent of corn stunt disease. Int. J. Syst. Evol. Microbiol. 1986, 36, 170-178. [CrossRef]

91. Zhao, Y.; Wang, H.; Hammond, R.W.; Jomantiene, R.; Liu, Q.; Lin, S.; Roe, B.A.; Davis, R.E. Predicted ATP-binding cassette systems in the phytopathogenic mollicute Spiroplasma kunkelii. Mol. Genet. Genom. 2004, 271, 325-338. [CrossRef] [PubMed]

92. Labroussaa, F.; Dubrana, M.-P.; Arricau-Bouvery, N.; Beven, L.; Saillard, C. Involvement of a minimal actin-binding region of Spiroplasma citri phosphoglycerate kinase in spiroplasma transmission by its leafhopper vector. PLoS ONE 2011, 6, e17357. [CrossRef] [PubMed]

93. Kwon, M.-O.; Wayadande, A.C.; Fletcher, J. Spiroplasma citri movement into the intestines and salivary glands of its leafhopper vector, Circulifer tenellus. Phytopathology 1999, 89, 1144-1151. [CrossRef] [PubMed]

94. Rottem, S. Interaction of mycoplasmas with host cells. Physiol. Rev. 2003, 83, 417-432. [CrossRef]

95. Killiny, N.; Batailler, B.; Foissac, X.; Saillard, C. Identification of a Spiroplasma citri hydrophilic protein associated with insect transmissibility. Microbiology 2006, 152, 1221-1230. [CrossRef]

96. Breton, M.; Duret, S.; Arricau-Bouvery, N.; Beven, L.; Renaudin, J. Characterizing the replication and stability regions of Spiroplasma citri plasmids identifies a novel replication protein and expands the genetic toolbox for plant-pathogenic spiroplasmas. Microbiology 2008, 154, 3232-3244. [CrossRef]

97. Shokal, U.; Yadav, S.; Atri, J.; Accetta, J.; Kenney, E.; Banks, K.; Katakam, A.; Jaenike, J.; Eleftherianos, I. Effects of co-occurring Wolbachia and Spiroplasma endosymbionts on the Drosophila immune response against insect pathogenic and non-pathogenic bacteria. BMC Microbiol. 2016, 16, 16. [CrossRef]

98. Guidolin, A.S.; Cônsoli, F.L. No fitness costs are induced by Spiroplasma infections of Aphis citricidus reared on two different host plants. Braz. J. Biol. 2019, 1678-4375. [CrossRef]

99. Hamilton, P.T.; Perlman, S.J. Host defense via symbiosis in Drosophila. PLoS Pathog. 2013, 9, e1003808. [CrossRef]

100. Yoshida, K.; Sanada-Morimura, S.; Huang, S.-H.; Tokuda, M. Influences of two coexisting endosymbionts, CI-inducing Wolbachia and male-killing Spiroplasma, on the performance of their host Laodelphax striatellus (Hemiptera: Delphacidae). Ecol. Evol. 2019, 9, 8214-8224. [CrossRef]

101. Herren, J.K.; Paredes, J.C.; Schüpfer, F.; Lemaitre, B. Vertical transmission of a Drosophila endosymbiont via cooption of the yolk transport and internalization machinery. MBio 2013, 4, e00532-12. [CrossRef] [PubMed]

102. Hayashi, M.; Watanabe, M.; Yukuhiro, F.; Nomura, M.; Kageyama, D. A nightmare for males? A maternally transmitted male-killing bacterium and strong female bias in a green lacewing population. PLoS ONE 2016, 11, e0155794. [CrossRef] 
103. Tinsley, M.C.; Majerus, M.E.N. A new male-killing parasitism: Spiroplasma bacteria infect the ladybird beetle Anisosticta Novemdecimpunctata (Coleoptera: Coccinellidae). Parasitology 2006, 132, 757-765. [CrossRef] [PubMed]

104. Matsuoka, Y.; Vigouroux, Y.; Goodman, M.M.; Sanchez, J.; Buckler, E.; Doebley, J. A single domestication for maize shown by multilocus microsatellite genotyping. Proc. Natl. Acad. Sci. USA 2002, 99, 6080-6084. [CrossRef] [PubMed]

105. Moya-Raygoza, G.; Garcia-Medina, C. Comparison of fecundity and body size of Mexican and Argentinian populations of Dalbulus maidis (Hemiptera: Cicadellidae). Ann. Entomol. Soc. Am. 2010, 103, 544-547. [CrossRef]

106. Oliveira, C.M.; Lopes, J.R.S.; Nault, L.R. Survival strategies of Dalbulus maidis during maize off-season in Brazil. Entomol. Exp. Appl. 2013, 147, 141-153. [CrossRef]

107. Bellota, E.; Medina, R.F.; Bernal, J.S. Physical leaf defenses-altered by Zealife-history evolution, domestication, and breeding - mediate oviposition preference of a specialist leafhopper. Entomol. Exp. Appl. 2013, 149, 185-195. [CrossRef]

108. Aráoz, M.V.C.; Jacobi, V.G.; Fernandez, P.C.; Albarracin, E.L.; Virla, E.G.; Hill, J.G.; Catalán, C.A.N. Volatiles mediate host-selection in the corn hoppers Dalbulus maidis (Hemiptera: Cicadellidae) and Peregrinus maidis (Hemiptera: Delphacidae). Bull. Entomol. Res. 2019, 109, 633-642. [CrossRef]

109. Chinchilla-Ramírez, M.; Borrego, E.J.; DeWitt, T.J.; Kolomiets, M.V.; Bernal, J.S. Maize seedling morphology and defence hormone profiles, but not herbivory tolerance, were mediated by domestication and modern breeding. Ann. Appl. Biol. 2017, 170, 315-332. [CrossRef]

110. Moya-Raygoza, G.; Cuevas-Guzmán, R.; Pinedo-Escatel, J.A.; Morales-Arias, J.G. Comparison of leafhopper (Hemiptera: Cicadellidae) diversity in maize and its wild ancestor teosinte, and plant diversity in the teosinte habitat. Ann. Entomol. Soc. Am. 2018, 112, 99-106. [CrossRef]

111. Carpane, P.; Laguna, I.G.; Virla, E.G.; Paradell, S.; Murúa, L.; Giménez-Pecci, M.D.L.P. Experimental transmission of corn stunt spiroplasma present in different regions of Argentina. Maydica 2006, 51, 461-468.

112. Bajet, N.B.; Renfro, B.L. Occurrence of corn stunt spiroplasma at different elevations in Mexico. Plant Dis. 1989, 73, 926-930. [CrossRef]

113. Raju, B.C.; Nyland, G. Enzyme-linked immunosorbent assay for the detection of corn stunt spiroplasma in plant and insect tissues. Curr. Microbiol. 1981, 5, 101-104. [CrossRef]

114. Barros, T.S.L.; Davis, R.E.; Resende, R.O.; Dally, E.L. Design of a polymerase chain reaction for specific detection of Corn stunt spiroplasma. Plant Dis. 2001, 85, 475-480. [CrossRef]

115. Wei, W.; Opgenorth, D.C.; Davis, R.E.; Chang, C.-J.; Summers, C.G.; Zhao, Y. Characterization of a novel adhesin-like gene and design of a real-time PCR for rapid, sensitive, and specific detection of Spiroplasma kunkelii. Plant Dis. 2006, 90, 1233-1238. [CrossRef]

116. Bigeard, J.; Colcombet, J.; Hirt, H. Signaling Mechanisms in Pattern-Triggered Immunity (PTI). Mol. Plant 2015, 8, 521-539. [CrossRef]

117. Park, Y.-S.; Ryu, C.-M. Insect stings to change gear for healthy plant: Improving maize drought tolerance by whitefly infestation. Plant Signal. Behav. 2016, 11, e0143879. [CrossRef]

118. Pieterse, C.M.J.; Dicke, M. Plant interactions with microbes and insects: From molecular mechanisms to ecology. Trends Plant Sci. 2007, 12, 564-569. [CrossRef]

119. Shi, G.; Zhang, Z.; Friesen, T.L.; Raats, D.; Fahima, T.; Brueggeman, R.S.; Lu, S.; Trick, H.N.; Liu, Z.; Chao, W. The hijacking of a receptor kinase-driven pathway by a wheat fungal pathogen leads to disease. Sci. Adv. 2016, 2, e1600822. [CrossRef]

120. Fougère, L.; Chartier, A.; Rhino, B.; Destandau, E.; Elfakir, C. Analysis of elicitors in different varieties of corn silk. Planta Med. 2016, 82, 109. [CrossRef]

121. Xu, S.; Zhou, W.; Pottinger, S.; Baldwin, I.T. Herbivore associated elicitor-induced defences are highly specific among closely related Nicotiana species. BMC Plant Biol. 2015, 15, 2. [CrossRef] [PubMed]

122. Abdul Malik, N.A.; Kumar, I.S.; Nadarajah, K. Elicitor and receptor molecules: Orchestrators of plant defense and immunity. Int. J. Mol. Sci. 2020, 21, 963. [CrossRef] [PubMed]

123. Montesano, M.; Brader, G.; Palva, E.T. Pathogen derived elicitors: Searching for receptors in plants. Mol. Plant Pathol. 2003, 4, 73-79. [CrossRef] 
124. Toruño, T.Y.; Stergiopoulos, I.; Coaker, G. Plant-pathogen effectors: Cellular probes interfering with plant defenses in spatial and temporal manners. Annu. Rev. Phytopathol. 2016, 54, 419-441. [CrossRef] [PubMed]

125. War, A.R.; Taggar, G.K.; Hussain, B.; Taggar, M.S.; Nair, R.M.; Sharma, H.C. Plant defence against herbivory and insect adaptations. AoB Plants 2018, 10, ply037.

126. Henry, G.; Thonart, P.; Ongena, M. PAMPs, MAMPs, DAMPs and others: An update on the diversity of plant immunity elicitors. Biotechnol. Agron. Soc. Environ. 2012, 16, 257-268.

127. Zipfel, C.; Robatzek, S. Pathogen-associated molecular pattern-triggered immunity: Veni, vidi...? Plant Physiol. 2010, 154, 551-554. [CrossRef]

128. Yamaguchi, Y.; Huffaker, A. Endogenous peptide elicitors in higher plants. Curr. Opin. Plant Biol. 2011, 14, 351-357. [CrossRef]

129. Maffei, M.E.; Arimura, G.-I.; Mithöfer, A. Natural elicitors, effectors and modulators of plant responses. Nat. Prod. Rep. 2012, 29, 1288-1303. [CrossRef]

130. Dangl, J.L.; McDowell, J.M. Two modes of pathogen recognition by plants. Proc. Natl. Acad. Sci. USA 2006, 103, 8575-8576. [CrossRef]

131. Deller, S.; Hammond-Kosack, K.E.; Rudd, J.J. The complex interactions between host immunity and non-biotrophic fungal pathogens of wheat leaves. J. Plant Physiol. 2011, 168, 63-71. [CrossRef] [PubMed]

132. Crabill, E.; Joe, A.; Block, A.; Van Rooyen, J.M.; Alfano, J.R. Plant immunity directly or indirectly restricts the injection of type III effectors by the Pseudomonas syringae type III secretion system. Plant Physiol. 2010, 154, 233-244. [CrossRef] [PubMed]

133. Orlovskis, Z.; Canale, M.C.; Haryono, M.; Lopes, J.R.S.; Kuo, C.-H.; Hogenhout, S.A. A few sequence polymorphisms among isolates of Maize bushy stunt phytoplasma associate with organ proliferation symptoms of infected maize plants. Ann. Bot. 2017, 119, 869-884. [CrossRef] [PubMed]

134. Zhang, J.; Lu, H.; Li, X.; Li, Y.; Cui, H.; Wen, C.K.; Tang, X.; Su, Z.; Zhou, J.M. Effector-triggered and pathogen-associated molecular pattern-triggered immunity differentially contribute to basal resistance to Pseudomonas syringae. Mol. Plant. Microbe Interact. 2010, 23, 940-948. [CrossRef]

135. Wu, X.-J.; Li, X.; Zhao, P.-F.; Li, N.; Wu, L.; He, Y.; Wang, S.-C. Comparative transcriptome profiling of two maize near-isogenic lines differing in the allelic state for bacterial brown spot disease resistance. J. Integr. Agric. 2015, 14, 610-621. [CrossRef]

136. Zhang, X.; Valdés-López, O.; Arellano, C.; Stacey, G.; Balint-Kurti, P. Genetic dissection of the maize (Zea mays L.) MAMP response. Theor. Appl. Genet. 2017, 130, 1155-1168.

137. Pan, J.; Zhang, M.; Kong, X.; Xing, X.; Liu, Y.; Zhou, Y.; Liu, Y.; Sun, L.; Li, D. ZmMPK17, a novel maize group D MAP kinase gene, is involved in multiple stress responses. Planta 2012, 235, 661-676. [CrossRef]

138. Kong, X.; Pan, J.; Zhang, M.; Xing, X.I.N.; Zhou, Y.A.N.; Liu, Y.; Li, D.; Li, D. ZmMKK4, a novel group C mitogen-Activated protein kinase kinase in maize (Zea mays), confers salt and cold tolerance in transgenic Arabidopsis. Plant Cell Environ. 2011, 34, 1291-1303. [CrossRef]

139. Kong, X.; Lv, W.; Zhang, D.; Jiang, S.; Zhang, S.; Li, D. Genome-wide identification and analysis of expression profiles of maize mitogen-activated protein kinase kinase kinase. PLoS ONE 2013, 8, e57714. [CrossRef]

140. Zou, H.; Wu, Z.; Yang, Q.; Zhang, X.; Cao, M.; Jia, W.; Huang, C.; Xiao, X. Gene expression analyses of ZmPti1, encoding a maize Pti-like kinase, suggest a role in stress signaling. Plant Sci. 2006, 171, 99-105. [CrossRef]

141. Hurni, S.; Scheuermann, D.; Krattinger, S.G.; Kessel, B.; Wicker, T.; Herren, G.; Fitze, M.N.; Breen, J.; Presterl, T.; Ouzunova, M.; et al. The maize disease resistance gene Htn1 against northern corn leaf blight encodes a wall-associated receptor-like kinase. Proc. Natl. Acad. Sci. USA 2015, 112, 8780-8785. [CrossRef] [PubMed]

142. Song, W.; Wang, B.; Li, X.; Wei, J.; Chen, L.; Zhang, D.; Zhang, W.; Li, R. Identification of immune related LRR-containing genes in maize (Zea mays L.) by genome-wide sequence analysis. Int. J. Genom. 2015, 2015, 231358.

143. Böhm, H.; Albert, I.; Fan, L.; Reinhard, A.; Nürnberger, T. Immune receptor complexes at the plant cell surface. Curr. Opin. Plant Biol. 2014, 20, 47-54. [CrossRef] [PubMed]

144. Yang, Q.; He, Y.; Kabahuma, M.; Chaya, T.; Kelly, A.; Borrego, E.; Bian, Y.; El Kasmi, F.; Yang, L.; Teixeira, P. A gene encoding maize caffeoyl-CoA O-methyltransferase confers quantitative resistance to multiple pathogens. Nat. Genet. 2017, 49, 1364. [CrossRef] [PubMed] 
145. Oliveira-Garcia, E.; Deising, H.B. Attenuation of PAMP-triggered immunity in maize requires down-regulation of the key $\beta$-1,6-glucan synthesis genes KRE5 and KRE6 in biotrophic hyphae of Colletotrichum graminicola. Plant J. 2016, 87, 355-375. [CrossRef]

146. Levy, J.G.; Gross, R.; Mendoza-Herrera, A.; Tang, X.; Babilonia, K.; Shan, L.; Kuhl, J.C.; Dibble, M.S.; Xiao, F.; Tamborindeguy, C. Lso-HPE1, an Effector of 'Candidatus Liberibacter solanacearum', Can Repress Plant Immune Response. Phytopathology 2020, 110, 648-655. [CrossRef]

147. Mandadi, K.K.; Scholthof, K.-B.G. Plant immune responses against viruses: How does a virus cause disease? Plant Cell 2013, 25, 1489-1505. [CrossRef]

148. Allen, C.; Bent, A.; Charkowski, A. Underexplored niches in research on plant pathogenic bacteria. Plant Physiol. 2009, 150, 1631-1637. [CrossRef]

149. Bektaş, A.; Hardwick, K.M.; Waterman, K.; Kristof, J. Occurrence of Hop latent viroid in Cannabis sativa with symptoms of cannabis stunting disease in California. Plant Dis. 2019, 103, 2699. [CrossRef]

150. Hoy, J.W. "Turning a blind eye to ratoon stunting disease of sugarcane in Australia" may be putting it too strongly without a lot more evidence. Plant Dis. 2019, 103, 790. [CrossRef]

151. Davis, M.J.; Augustin, B.J. Occurrence in Florida of the bacterium that causes bermudagrass stunting disease. Plant Dis. 1984, 68, 1095-1097. [CrossRef]

(C) 2020 by the authors. Licensee MDPI, Basel, Switzerland. This article is an open access article distributed under the terms and conditions of the Creative Commons Attribution (CC BY) license (http://creativecommons.org/licenses/by/4.0/). 